\title{
A New Strategy for Acetogenic Bacteriacell Growth and Metabolites Production Using Syngas in Lab Scale
}

\author{
Roberta R. Ribeiro, Fabiana Coelho, Tatiana F. Ferreira, Priscilla F. F. Amaral \\ (Escola de Química/Universidade Federal do Rio de Janeiro, Brazil)
}

\begin{abstract}
Syngas fermentation by acetogenic bacteria present a major bottleneck, which is the low solubility of the substrates $\left(\mathrm{CO}\right.$ and $\left.\mathrm{CO}_{2}\right)$ and, therefore, the low productivity caused by low cell density. In lab scale, many studies are conducted in serum bottles and agitated in incubation shakers with bottles kept vertically. In the present study, the serum bottles were kept horizontally in a new strategy to increase turbulence and, as a consequence, the mas transfer. Cell growth of Clostridium carboxidivorans (DSM 15243), Clostridium ragsdalei (DSM 15248) and Clostridium ljungdahlii (DSM 13528) was increased by the increase in the availability of $\mathrm{CO}$ and $\mathrm{CO}_{2}$ in the liquid medium. Cell growth of C.carboxidivoransincreased 3.7 times and the specific growth rate became $50 \%$ higher. Ethanol and acetic acid production were also favored by this strategy. C.carboxidivorans was thebest specie for ethanol production.
\end{abstract}

Keywords: syngas, Clostridium, ethanol, hybrid process

\section{Introduction}

Currently there is a worldwide interest in usingbiomass as an environmentally friendly and renewable energy source. Many concerns point outthe need to use renewable feedstock as part of the energy matrix and as a possible replacement for fossil fuels. An interesting pathway for biomass transformation isits thermochemical conversion through gasification,producingsynthesis gas (syngas), a gas mixture composed mainly of $\mathrm{CO}, \mathrm{CO}_{2}$ and $\mathrm{H}_{2}$. Subsequently, thesyngas producedcan be converted to a range of liquid fuels and hydrocarbons using transition metals as catalyst, which is known as Fischer-Tropsch process [1]. An alternative approach for biofuels production is the 'syngas fermentation', a biotechnological process which is currently under intensive research and development. This hybrid thermochemical/biochemical processcan convert gasinto ethanol andvalue-added liquid productsusing biocatalysts. This routeis a promising technologyand much more attractive due to several benefits over Fischer-Tropsch process and traditional ways of producing ethanol[2], [3].

Although carbon monoxide is highly toxicfor most organisms, several microorganismscan tolerate and even live chemoautotrophically on this gas.Therefore, itoffers an exciting opportunity to produce fuels and chemicals from non-dedicated crops, agriculture residues and forestrymaterials through fermentation. Some acetogenic bacteria have been described as capable ofconsuming $\mathrm{CO}$ and synthesizing acetate, ethanol and other products [4]. For syngas fermentation,thebacterial genus Clostridium is most used, which iscategorized as carboxydotrophichomoacetogens. The metabolic pathway enabling $\mathrm{CO}$ utilization inClostridium species iscalledreductive acetyl-CoA pathway, also known as the Wood-Ljungdahl pathway, in which syngas is convertedto acetyl-CoA. Then, theacetyl-CoA can be: (i) incorporated into biomass; (ii) excreted as acetate, which can be further reduced to acetaldehyde and then ethanol; and (iii) directly reduced to acetaldehyde and then ethanol [4], [5]. During syngas fermentation, the acidogenesis occurs at favorable growth conditions with sufficient nutrient supply(vitamins and minerals), optimal $\mathrm{pH}$ and temperature, and no end-product inhibition but somewhat limited electron donor supply $\left(\mathrm{CO}\right.$ or $\left.\mathrm{H}_{2}\right)$. On the other hand, the solventogenesis is favored during slow growth in abundantly presenceofanelectron donor, and unfavored at lower temperatures and $\mathrm{pH}$ and limited nutrient concentration.Another contributing factor for solventogenesis is a very likely end-product inhibition caused by high concentrations of undissociated acetic and butyric acids [6].

Syngas fermentation has many advantages such asits conduction at room temperature and pressure avoiding high energetic costs;feedstock flexibility, as in lignocellulosic and municipal solid wastes; and utilization of all components from the lignocellulosic biomass, including lignin.However, this processhas a low productivity associated with low cell density, enzyme inhibition and mass transfer limitations [7].The mass transfer limitation is a major challengefor syngas fermentation due to gases low solubility in water and media and reactors configuration [8], [9].The gas-liquid mass transfer rates are only $77 \%(\mathrm{CO})$ and $65 \%\left(\mathrm{H}_{2}\right)$ of that for oxygen. In lab scale, the serum bottles used for anaerobic bacteria growth are kept in vertical position, which compromises even more the mass transfer. Therefore, low concentrations of dissolved $\mathrm{CO}$ and $\mathrm{H}_{2}$ result in an insufficient substrate supply for microorganisms and a major bottleneck for a full-scale application of syngas fermentation [7], [10]. The present work aims to study the kinetic growth of Clostridium carboxidivorans(DSM 15243), Clostridium ragsdalei (DSM 15248) and Clostridiumljungdahlii(DSM 13528)during syngas fermentation with serum bottles in vertical and horizontal position in order to investigate the influence of higher liquid turbulence in growth kinetic parameters. 
2.1Microorganism

\section{Materials}

Clostridium carboxidivorans (DSMZ 15243), Clostridium ragsdalei (DSM 15248)and Clostridiumljungdahlii (DSM 13528) were provided by the German Collection of Microorganisms and Cell Cultures (DSMZ, Braunschweig, Germany).

\subsection{Synthesis Gas}

The synthesis gas, or syngas, obtained from White Martins Gases Industriais Ltda.is composed of hydrogen (40\%), carbon monoxide (25\%), carbon dioxide (10\%), nitrogen (10\%) and methane (11\%).

\subsection{Media and Culture Preparation}

Thestrains were cultivatedseparatelyin standard growth medium recommended by $\mathrm{ATCC}^{\circledR} 2713$. The medium containstryptone $(10.0 \mathrm{~g} / \mathrm{L})$, gelatin peptone $(10.0 \mathrm{~g} / \mathrm{L})$, yeast extract $(5.0 \mathrm{~g} / \mathrm{L})$, glucose $(1.0 \mathrm{~g} / \mathrm{L})$, sodium chloride $(5.0 \mathrm{~g} / \mathrm{L})$, L-arginine $(1.0 \mathrm{~g} / \mathrm{L})$, sodium pyruvate $(1.0 \mathrm{~g} / \mathrm{L})$, menadione $(0.0005 \mathrm{~g} / \mathrm{L})$ and haemin $(0.005 \mathrm{~g} / \mathrm{L})$.This liquid mediawas degassed and dispensed anaerobically usingsyngas, and the $100 \mathrm{~mL}$-glass serum bottles were sealed with impermeable butyl rubber septum-type stoppers and aluminum crimp seals before sterilization in autoclave at $121{ }^{\circ} \mathrm{C}$ and $0.5 \mathrm{~atm}$ for 15 minutes.

\subsubsection{Inoculum}

The inoculum was prepared in $100 \mathrm{~mL}$ serum bottles containing 50 mLof liquid media. The bottles were pressurized to 1.2atmusingsyngasin order to create extremely anaerobic conditions. The pressure was maintained by impermeable butyl rubber septum-type stoppers and aluminum crimp seals. The cells were transferredfrom cultivated $\mathrm{ATCC}^{\circledR} 2713$ media stored at refrigerator temperature (at $4^{\circ} \mathrm{C}$ ) in one passageand wereincubated in a shaker at $37^{\circ} \mathrm{C}$ and $150 \mathrm{rpm}$ for $24 \mathrm{~h}$, with the bottlesplaced horizontally. The inoculum size used was $10 \%(\mathrm{v} / \mathrm{v})$.

\subsection{Bacterial growth kinetics}

After $24 \mathrm{~h}$ inoculum cultivation, approximately $5.0 \mathrm{~mL}$ of cells were transferred to the sealed bottles containing ATCC $^{\circledR} 2713$ medium and syngas using sterilized syringe and needles.In order to study the bacterialgrowth,two strategies were implemented during cultivation in shaker.After inoculation, the bottles containing one bacteria specie were incubatedat $150 \mathrm{rpm}$ and $37^{\circ} \mathrm{C}$ for $120 \mathrm{~h} \mathrm{in}$ a shaker and were placed horizontally or vertically during batch fermentation. The same procedure was adopted for three species: $C$. carboxidivorans, C. ljungdahlii and C. rasgdalei.

During sampling, syngas was added to the bottles to maintain the pressure in the bottle constant.

\section{Analytical Methods}

Cell growth was determined bymeasuringtheoptical density at $600 \mathrm{~nm}$ using aspectrophotometer Shimadzu UV-1201 (Japan). Samples of $2.0 \mathrm{~mL}$ were takenduring fermentation using asyringe for product and by-product analysis. The quantitative analysis for fermentation products and by-productswas conducted in a High Performance Liquid Chromatography (HPLC) equipped with a Refractive Index (RI) detector and an Aminex-HPX-87H ion exchange column (Biorad, Munich, Germany). The column was operated at $60{ }^{\circ} \mathrm{C}$ and sulfuric acid $(0.005 \mathrm{M})$ was used asmobile phase. A $20 \mu \mathrm{l}$ sample was injected at a constant flow of $0.8 \mathrm{~mL}$ $\mathrm{min}^{-1}$. Peaks were identified by comparison with known concentrations of analytical standards of all fermentation products (Sigma Chemical Co., St. Louis, Missouri), which werediluted in Milli-Q water and injectedin triplicate in order to prepare a standard curve relating the peak area to theproducts concentration.

\section{Results And Discussion}

Cell growth, ethanol and acetate production were monitored for three species of Clostridium in ATCC medium with syngas. In order to investigate the influence of mass transfer in growth and metabolites production the bottles were kept positioned vertically or horizontally in the shaker, as shown in Fig. 1.

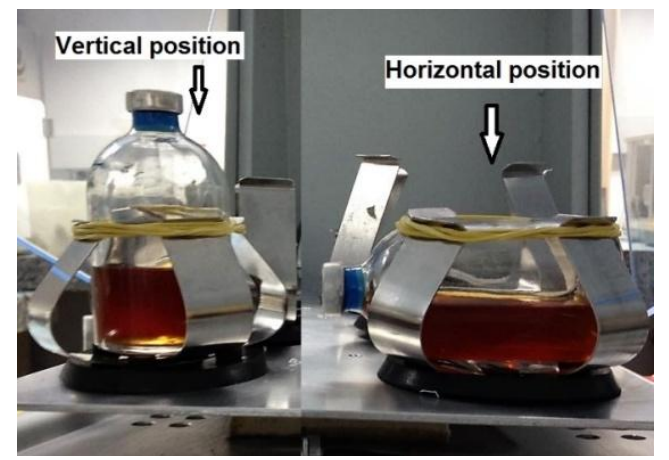

Figure 1. Serum bottles kept vertically and horizontally in the shaker. 
The bottles kept horizontally present a higher turbulence in liquid and, therefore a higher mass transfer is possible. The results obtained are presented in Fig. 2 and Table 1. The growth kinetic profile of C. rasgdalei and $C$. ljungdahlii with bottles kept vertically are not shown because these were not significant.

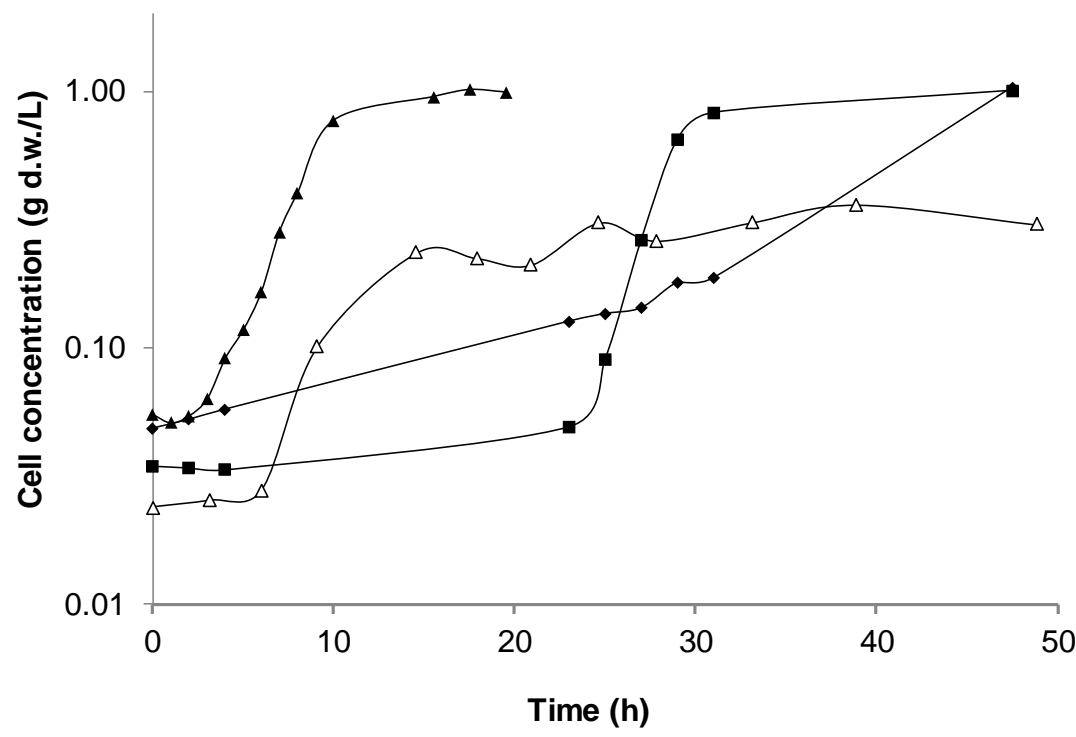

Figure 2. Kinetic of cell growth for C.carboxidivorans with bottles kept vertically $(\Delta)$, and C.carboxidivorans $(\mathbf{\Lambda})$, C.ljungdahlii $(\bullet)$ and C.ragsdalei( $(\mathbf{)})$ with bottles kept horizontally.

Table 1. Kinetic Parameters, ethanol and acetate concentration and productivity in fed-batch fermentation operating at $37^{\circ} \mathrm{C}, 150 \mathrm{rpm}$ and with serum bottles kept in different positions.

\begin{tabular}{|c|c|c|c|c|c|c|c|c|}
\hline Organism & $\begin{array}{l}\text { Serum bottle } \\
\text { position }\end{array}$ & $\begin{array}{l}\mathbf{t}_{\text {lag }} \\
(\mathbf{h})^{\mathrm{a}}\end{array}$ & $\begin{array}{l}\square X \\
(\mathrm{~g} / \mathrm{L})^{\mathrm{b}}\end{array}$ & $\mu\left(h^{-1}\right)^{c}$ & $\begin{array}{l}P_{\text {EtOH }}(m \\
\text { g/L })^{d}\end{array}$ & $\begin{array}{l}\text { Q }_{\text {EtOH }} \\
(\mathrm{mg} / \text { L.h })^{\mathrm{e}}\end{array}$ & $\begin{array}{l}P_{\mathrm{AC}} \\
(\mathrm{mg} / \mathrm{L})^{\mathrm{f}}\end{array}$ & $\begin{array}{l}Q_{\mathrm{AC}} \\
(\mathrm{mg} / \text { L.h })^{\mathrm{g}}\end{array}$ \\
\hline $\begin{array}{l}\text { Clostridium } \\
\text { carboxidivorans }\end{array}$ & Vertically & 6 & 0.337 & 0.24 & ND & ND & 1380.0 & 40.0 \\
\hline $\begin{array}{l}\text { Clostridium } \\
\text { carboxidivorans }\end{array}$ & \multirow[t]{3}{*}{ Horizontally } & 3 & 1.245 & 0.37 & 378.7 & 15.8 & 1704.6 & 71.0 \\
\hline $\begin{array}{l}\text { Clostridium } \\
\text { ljungdahlii }\end{array}$ & & 27 & 0.987 & 0.10 & 144.2 & 6.3 & 930.8 & 192.0 \\
\hline $\begin{array}{l}\text { Clostridium } \\
\text { ragsdalei }\end{array}$ & & 23 & 0.968 & 0.38 & 150.5 & 5.2 & 802.9 & 32.1 \\
\hline
\end{tabular}

a: lag phase time; b: Cell growth, calculated by the difference between final and initial cell concentration (in g dry weight of cells/L); c: Specific growth rate, calculated at exponential growth phase; d: Ethanol production (maximum concentration achieved); e: Ethanol productivity; f:acetateconcentration; g:acetate productivity.

Figure 2 depicts that the higher turbulence promoted by the horizontal position increased cell growth since no growth was detected for $C$. rasgdalei and $C$. ljungdahlii when a vertical position was used and a significant growth was observed for these species cultivated in the same conditions, but horizontally. For $C$. carboxidivorans it is also possible to observe that higher cell growth is achieved with higher mass transfer (bottles kept horizontally), with higher specific growth rate and cell production and inferior lag phase (Table 1). Comparing the growth kinetics of the tree species (Fig. 2, Table 1), similar profiles are observed for $C$. carboxidivorans and $C$. rasgdalei, with, approximately, the same specific growth rate $(\mu)$, except for the lag phase that was higher for $C$. rasgdalei. Allthree species presented a similar cell growth when conducting the fermentation with bottles horizontally positioned, reachinga cell concentration of approximately $1.0 \mathrm{~g} / \mathrm{L} \mathrm{DW}$ at the stationary phase. However, $C$. carboxidivorans had a smaller lag phase, which indicates a higher productivity in terms of biomass production.

Hurst and Lewis [12] conducted a study to evaluate the influence of pressure in cell growth during fermentation using C. carboxidivorans and obtained a lag phase of 17 hours and the beginning of the exponential phase at 22 hours with $1.35 \mathrm{~atm}$. This study also shows a final cell concentration of $1.0 \mathrm{~g} / \mathrm{L}$ at 2.0 atm after 70 hours of fermentation[12].In the present work, it was possible to achieve a similar cell concentration $(1.245 \mathrm{~g} / \mathrm{L})$ after 15 hours of experiment, with a lower lag phase (3 hours) with lower pressure $(1.2 \mathrm{~atm}) . C$. ljungdahliiin syngas fermentation presented a lag phase of approximately 10 hours and a final cell concentration of $1 \mathrm{~g} / \mathrm{L}$ in 50 hours of fermentation at a pressure of $1.20 \mathrm{~atm}$ [13].Both studies ([12] and [13]) were conducted 
with bottles kept in a vertical position, and, therefore, with lower gas transfer rate. With bottles kept horizontally it was possible to increase $\mathrm{CO}$ and $\mathrm{CO}_{2}$ transfer to the liquid phase, which might have reduced lag phase because of the availability these two substrates promptly.Higher gas transfer caused by the turbulence of the bottles in the horizontal position increased also ethanol and acetic acid production as Table 1 shows. No production was detected for $C$. ljungdahlii and C. rasgdalei with bottles kept vertically and inferior values were observed for $C$. carboxidivorans in relation to the bottles kept horizontally. Productivity of ethanol and acetic acid were also higher when $\mathrm{CO}$ and $\mathrm{CO}_{2}$ were rapidly available. Table 1 also shows that $C$. carboxidivorans was a better ethanol producer between the three clostridia species studied.

\section{Conclusions}

The increase in the availability of substrates caused by the higher turbulence when serum bottles were kept in a horizontal position reduced lag phase in 3 hours and cell growth was 3.7 times higher with a $50 \%$ increase in the specific growth rate in relation to the bottles kept vertically, for $C$. carboxidivorans. It also increased acetic acid and ethanol production. For $C$. ljungdahlii and $C$. reasgdalei, this strategy made possible cell growth and metabolites production, which was not observed when syngas was slightly dissolved in the medium (bottles kept vertically). C. carboxidivorans was the best acetogenic specie for acetic acid and ethanol production.

\section{References}

[1]. B. S. Rahardjo,The assessment of syngas utilization by fichertropsch synthesis in the slurry-bed reactor using $\mathrm{Co} / \mathrm{SiO} 2$ catalyst,International Journal of Engineering and Applied Sciences, 4, 2013, 20-39.

[2]. M.Mohammadi, G. D. Najafpour, H. Younesi, P. Lahijani, M. H. Uzir, and A. R. Mohamed, Bioconversion of synthesis gas to second generation biofuels: a review, Renewable and Sustainable Energy Reviews, 15, 2011, 4255-4273.

[3]. J Vandecasteele,Experimental and modelling study of pure-culture syngas fermentation for biofuels production, master diss., Faculty of Bioscience Engineering from Ghent University, Ghent, Belgium, 2016.

[4]. M. Köpke, C. Mihalcea, J. C. Bromley, and S. D. Simpson, Fermentative production of ethanol from carbon monoxide, Current Opinion in Biotechnology, 22, 2011, 320-325.

[5]. M. Köpke, C. Held, S. Hujer, H. Liesegang, A. Wiezer, A. Wollherr, A. Ehrenreich, W. Liebi, G. Gottschalk, and P. Dürre, Clostridium ljungdahlii represents a microbial production platform based on syngas, Proceedings of the National Academy of Sciences, 107, 2010, 13087-13092.

[6]. H. Richter, M. Martin, and L. Angenent, A two-stage continuous fermentation system for conversion of syngas into ethanol, Energies, 6, 2013, 3987-4000.

[7]. M. D. Bredwell, P. Srivastava, and R. M. Worden, Reactor design issues for synthesis gas fermentations, BiotechnologyProgress, $15,1999,834-844$.

[8]. M. Devarapalli, H. K. Atiyeh, J. R. Phillips, R. S. Lewis, and R. L. Huhnke, Ethanol production during semi-continuous syngas fermentation in a trickle bed reactor using Clostridium ragsdalei,Bioresource Technology, 209, 2016, 56-65.

[9]. Y. Shen, R. Brown, and Z. Wen, Syngas fermentation of Clostridium carboxidivorans P7 in a hollow fiber membrane biofilm reactor: Evaluating the mass transfer coefficient and ethanol production performance,BiochemicalEngineering Journal, 85, 2014, 21-29.

[10]. P-H Lee. Syngas fermentation to ethanol using innovative hollow fiber membrane, doctoral diss., Iowa State University, Iowa, 2010.

[11]. P. Maddipati, H. K. Atiyek, D. D., Bellmer, R. L. Huhnke, Ethanol production from syngas by Clostridium strain P11 using corn steep liquor as a nutrient replacement to yeast extract, Bioresource Technology, 102, 2011, 6494-6501.

[12]. K.M. Hurst, and R.S. Lewis, Carbon monoxide partial pressure effects on the metabolic process of syngas fermentation, Biochemical Engineering Journal, 48, 2010, 159-165.

[13]. A. Dadak, M. Aghbashlo, M. Tabatabaei, H. Younesi, and G. Najafpour, Using exergy to analyze the sustainability of fermentative ethanol and acetate production from syngas via anaerobic bacteria (Clostridium ljungdahlii), Sustainable Energy Technologies and Assessments, 15, 2016, 11-19. 